\title{
Good Institutions are not enough: Ongoing Challenges of East German Development
}

\author{
Wendy Carlin
}

\author{
CESIFO WORKING PAPER NO. 3204
}

CATEGORY 6: Fiscal POLICY, MACROECONOMICS AND GROWTH

OCTOBER 2010

\footnotetext{
An electronic version of the paper may be downloaded

- from the SSRN website:

- from the RePEc website:

www.SSRN.com

WwW.RePEc.org

- from the CESifo website:

www.CESifo-group.org/wp
} 


\title{
Good Institutions are not enough: Ongoing Challenges of East German Development
}

\begin{abstract}
A major theme in accounts of the transitional recession and delayed convergence in postcommunist economies is the role of institutions. Yet via unification, East Germany had immediate access to credible, high quality institutions. This paper argues that success in a capitalist economy depends not only on high quality institutions but also on finding one's niche in the international division of labour. East Germany's experience highlights the long shadow cast by the period under communism over the economy's ability to find its comparative advantage in tradeables on a scale adequate for self-sustaining growth.
\end{abstract}

JEL-Code: O43, O52.

Keywords: transition, institutions, East Germany, tradeables, convergence.

\author{
Wendy Carlin \\ Department of Economics \\ University College London \\ Gower Street \\ UK - London WC1E 6BT \\ w.carlin@ucl.ac.uk
}

This paper was prepared for the Keynote lecture at the Conference '20 years German Unification - From Transition to European Integration' Conference of the Halle Institute for Economic Research (IWH) in co-operation with the Martin-Luther-University HalleWittenberg and the Collaborative Research Center 580 "Social Developments in Postsocialistic Societies". I am grateful to Maxim Mai for excellent research assistance and to Andrea Boltho for comments. 


\section{Introduction}

An underlying theme in the analysis of transition in the former Soviet bloc is that of disappointment (for example, Kornai, 2006, Easterlin, 2009, Grosfeld and Senik, 2009, Sanfey and Teksoz, 2007). An extreme reflection of this is that in Russia in 2006 after eight years of strong economic performance when asked the question "Would you like your kids to grow up in an environment like the modern Russia or like the Soviet Union?" about half of survey respondents would prefer their children to grow up in the Soviet Union (Denisova et al. 2010 forthcoming). Transition has proved much more protracted than anticipated - a rapid catch-up by the central and eastern European transition economies to European Union living standards did not occur. A substantial research effort has attempted to discover why well-educated labour forces with good levels of physical infrastructure in an era of financial globalization and trade integration were unable to take advantage of the apparently 'low-hanging fruit' available by introducing existing technologies, and to reap the reward of rapid catch up. Much of this research pointed to the neglect at the outset of transition of the challenges involved in creating market economy institutions. The East German transition provides a useful comparative case study in addressing this question. Unlike other transition economies, East Germany acquired high quality and credible market institutions by virtue of unification. Yet its performance was in many ways similar to that of its Central and Eastern European comparators: a transitional recession followed by slow convergence.

In this paper I begin by comparing the economic performance of East Germany and its transition economy neighbours with two earlier European catch-up episodes - the post war catch-up of West Germany and the post 1960 catch-up of Southern European economies. In Section 3, I use a growth diagnostics framework to narrow down the proximate causes of delayed catch-up. For transition economies, this highlights the potential role of institutional weakness; for East Germany, where institutional weakness was more rapidly overcome, it draws attention to market failures in the sense of an inadequate supply of good investment projects. The fourth section begins by noting that the difficulty for East Germany in discovering its niche in the international division of labour was reflected in a very low employment rate in industry. I use the concept of the 'export base' to evaluate East German progress in 
achieving sustainable development. In the concluding section I draw attention to the role of more balanced growth in West Germany in contributing to East Germany's ability to avoid a Mezzogiorno scenario.

\section{Comparative catch-up episodes - expectations and outcomes}

Expectations about the catch-up of transition economies that had already industrialized before the second world war were likely to have been influenced by previous large-scale economic reforms. The western zones of Germany after the currency reform and price liberalization of 1948, and Spain, Portugal and Greece after the liberalizations in the late 1950s and early 1960s experienced rapid convergence toward the long-run growth path (Cesar das Neves, 1996, Eichengreen, 2006, Prados de la Escosura and Sanz, 1996). Figure 1 illustrates the success of these earlier European post-reform catch-up episodes by showing the long run growth of per capita GDP in West Germany and Spain along with the UK as comparator from 1920 to 2008. The speed with which West German per capita GDP rejoined the long-run growth path defined by the UK is clear, as is the acceleration of growth in Spain following the reforms that began in 1959.

Figure 1. Long-run Growth Paths and Post-Reform Catch-up: UK, West Germany and Spain, 1920-2008

GDP per capita at PPP (log); Gheary-Khamis \$1990

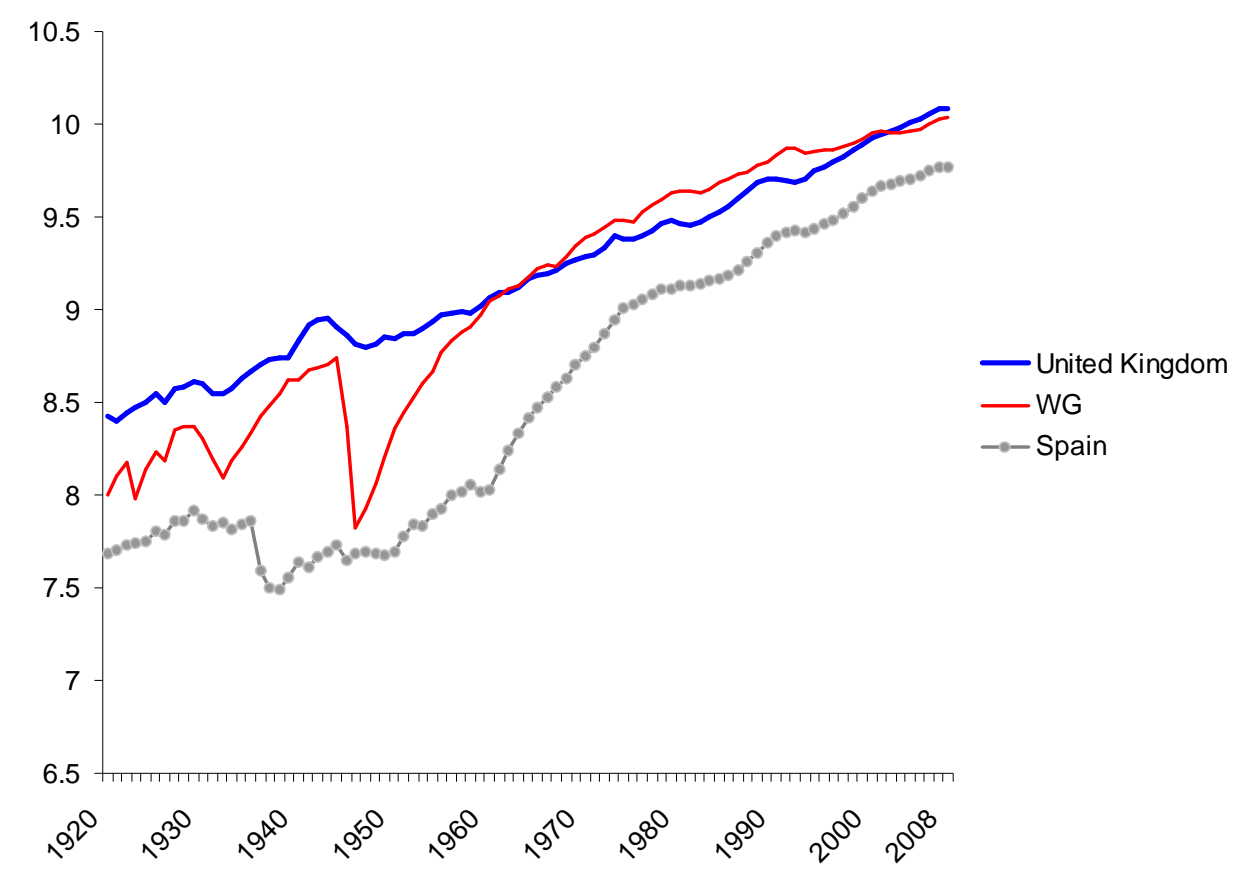

Source: The Conference Board and Groningen Growth and Development Centre, Total Economy Database, June 2009 http://www.conference-board.org/economics/ 
For the Central and East European post-communist countries implementing policies of stabilization, liberalization and privatization, and with the prospect of accession to the European Union, similar expectations were natural. Yet the outcome was very different as Fig. 2 demonstrates (using the case of Austria, a close comparator of the Visegrad countries in the 1920 s as the bench-mark).

Figure 2. Long-run Growth Paths and Post-Transition Performance: Austria, Czechoslovakia, Hungary. 1920-2008

GDP per capita at PPP (log); Gheary-Khamis $\$ 1990$

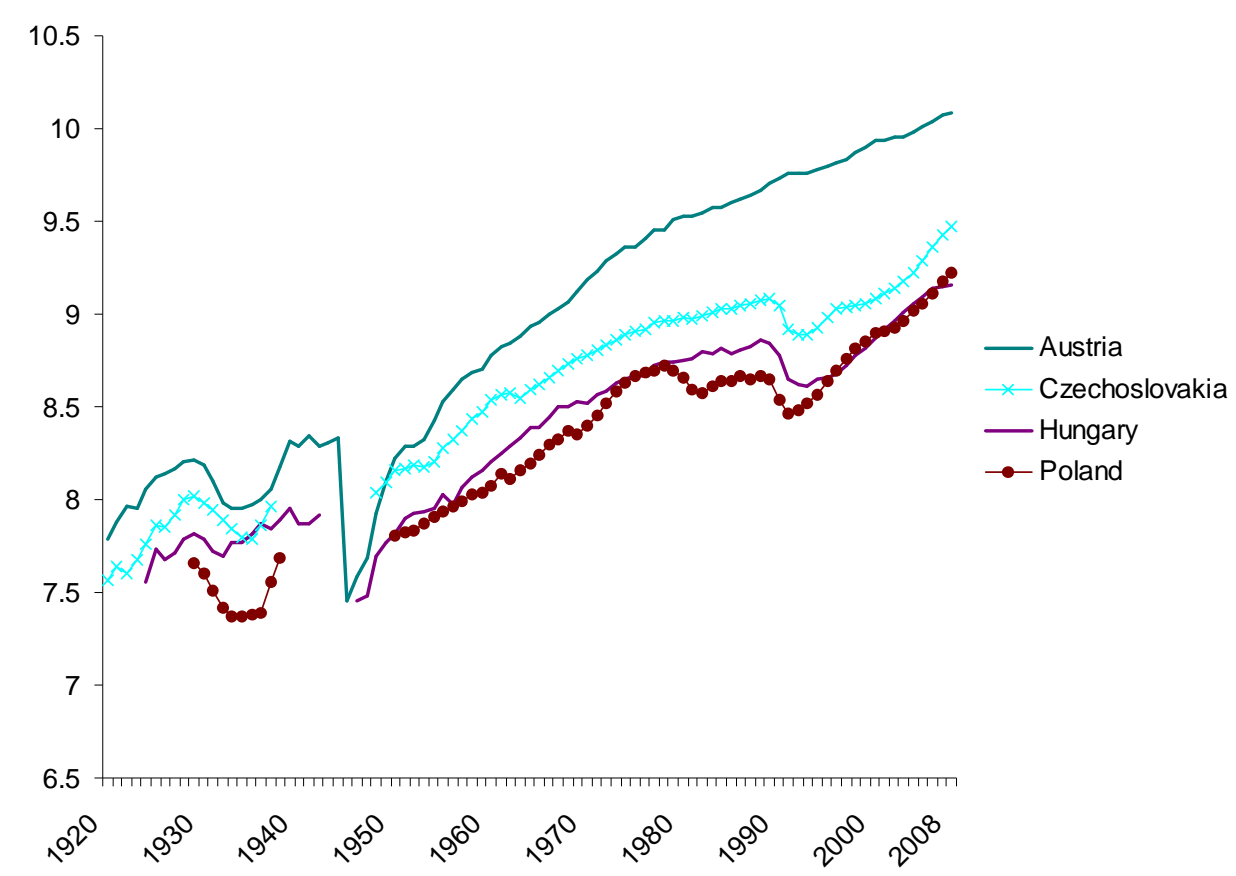

Source: The Conference Board and Groningen Growth and Development Centre, Total Economy Database, June 2009 http://www.conference-board.org/economics/

Figure 3 compares the growth rates of per capita GDP for the post-communist transition with those of West Germany after 1948 and Spain from 1960. When East Germany is added to comparison, its mediocre record is evident. 
Figure 3. Post-reform Growth: Comparison of Post-Transition Countries (1990-2008) with West Germany (1948-66) and Spain (1960-78)

Index 1 = 1990 for Transition; 1936 for West Germany; 1960 for Spain

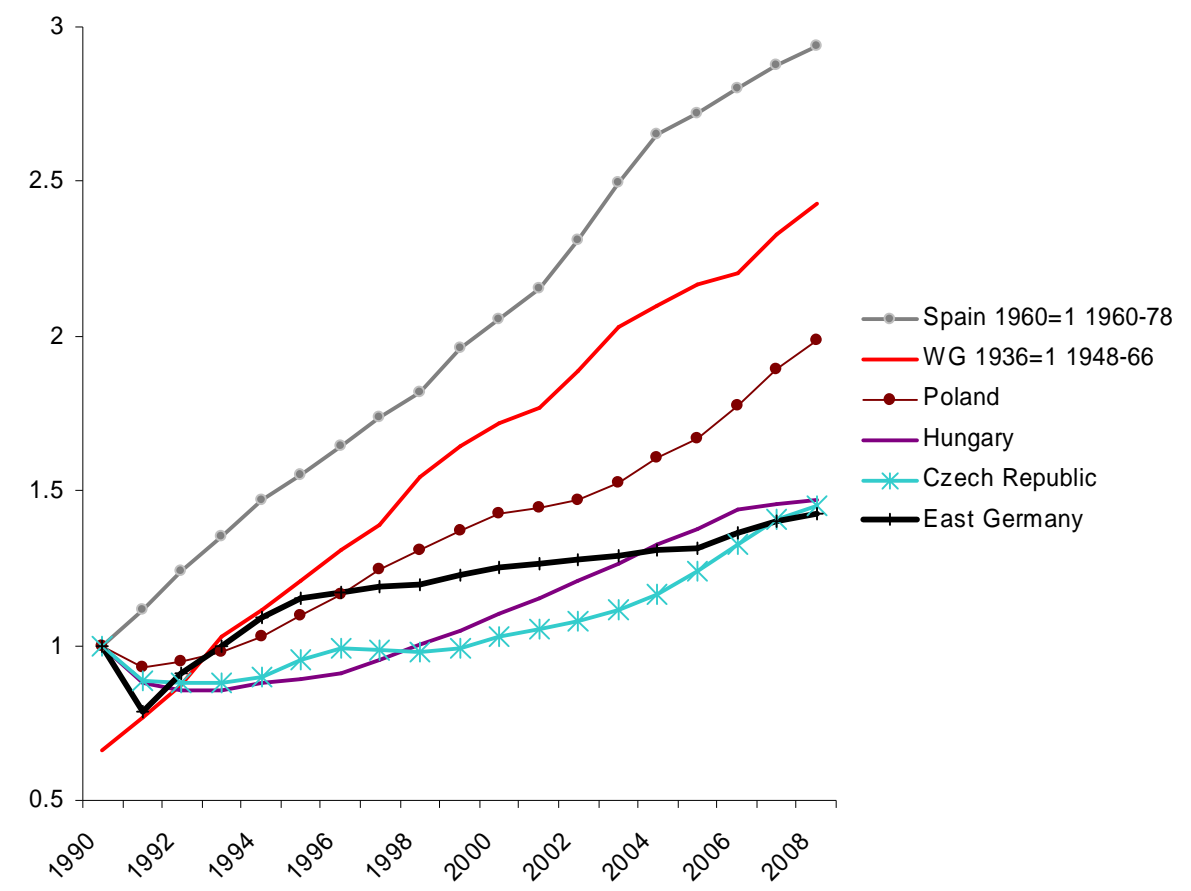

Sources: The Conference Board and Groningen Growth and Development Centre, Total Economy Database, June 2009,http://www.conference-board.org/economics/; Volkswirtschaftliche Gesamtrechnungen der Länder (2009)

Notes: East Germany Conference Board data linked to Volkswirtschaftliche Gesamtrechnungen der Länder (2009). Indices are GDP per Capita, in 1990 GK\$

A closer look at the catch-up of the Southern European countries following the liberalization reforms around 1960 provides a context for evaluating post-transition performance. From an accounting perspective, differences in GDP per capita can be decomposed into differences in labour productivity and in employment rates. ${ }^{2}$ Looking first at labour productivity, Fig. 4 presents PPP data on value added per employed worker, a broad measure of economy-wide labour productivity. It takes France as the comparator for two exercises: first for the catch-up of the Southern economies from 1960 and second, for the post-communist catch-up from 1991. Several points emerge from the comparison. First, with the exception of Slovenia, the Eastern European countries were further behind France in 1991 than were the Southern countries behind France in 1960 at the beginning of their catch-up. The

\footnotetext{
${ }^{2}$ Strictly speaking, GDP/Population $=$ GDP/E $*$ E/Population of working age $*$ Population of working age/Population. In what follows, I leave aside cross-country variations and changes over time in the ratio of working age population to the population as a whole.
} 
Southern catch-up in the subsequent 17 years was mostly more rapid than that in the 17 post transition years.

Against the performance of its Eastern European comparators, East Germany's performance was reasonably good and its catch-up to France was similar to that achieved by Greece from 1960 to 1977 . Fig. 4 also highlights the fact that the Southern productivity catch-up had virtually stopped by 1977 - in the subsequent 31 years, the labour productivity gap with France scarcely altered.

Figure 4. Two European Post-reform Catch-up Episodes: Southern Europe Post 1960; Transition Economies Post 1990

Productivity Index: France $=100$

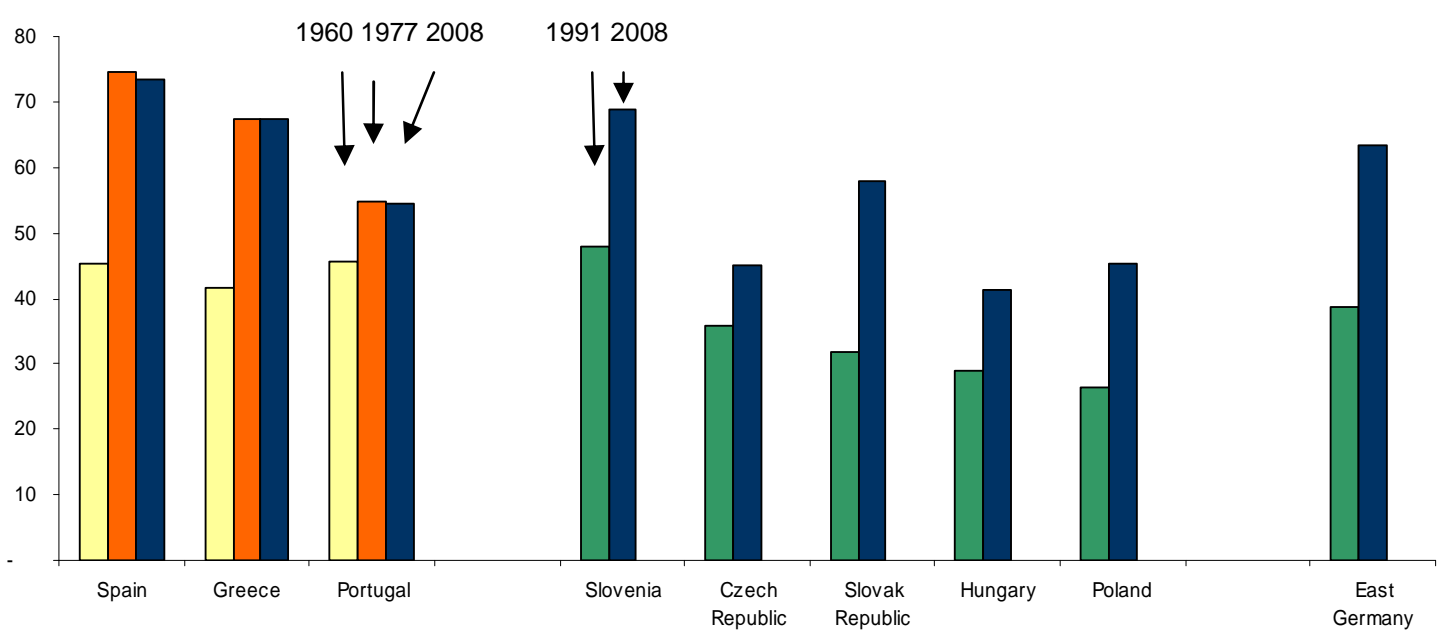

Sources: The Conference Board Total Economy Database, January 2010, http://www.conferenceboard.org/economics/database.cfm, Volkswirtschaftliche Gesamtrechnungen der Länder (2009)

In the Southern catch up, rising employment rates from the 1980s (especially via increased women's participation) allowed further GDP per capita catch up to take place in the absence of faster growth in output per worker than in France. Fig. 5 shows the decomposition of GDP per capita differences relative to France for the three Southern and five Eastern comparators of East Germany. In 2008, East Germany looked quite similar to Greece in terms of GDP per capita, productivity and employment rate. Its performance in GDP per capita and productivity was second to that of Slovenia and clearly ahead of the other CEECs. It is interesting that among the transition economies, employment rates were considerably higher relative to France in 
Slovenia and the Czech Republic than in Slovakia, Hungary or Poland. East Germany was between the two groups.

Figure 5. GDP per capita, Productivity and Employment Rates in 2008 Index: France $=100$

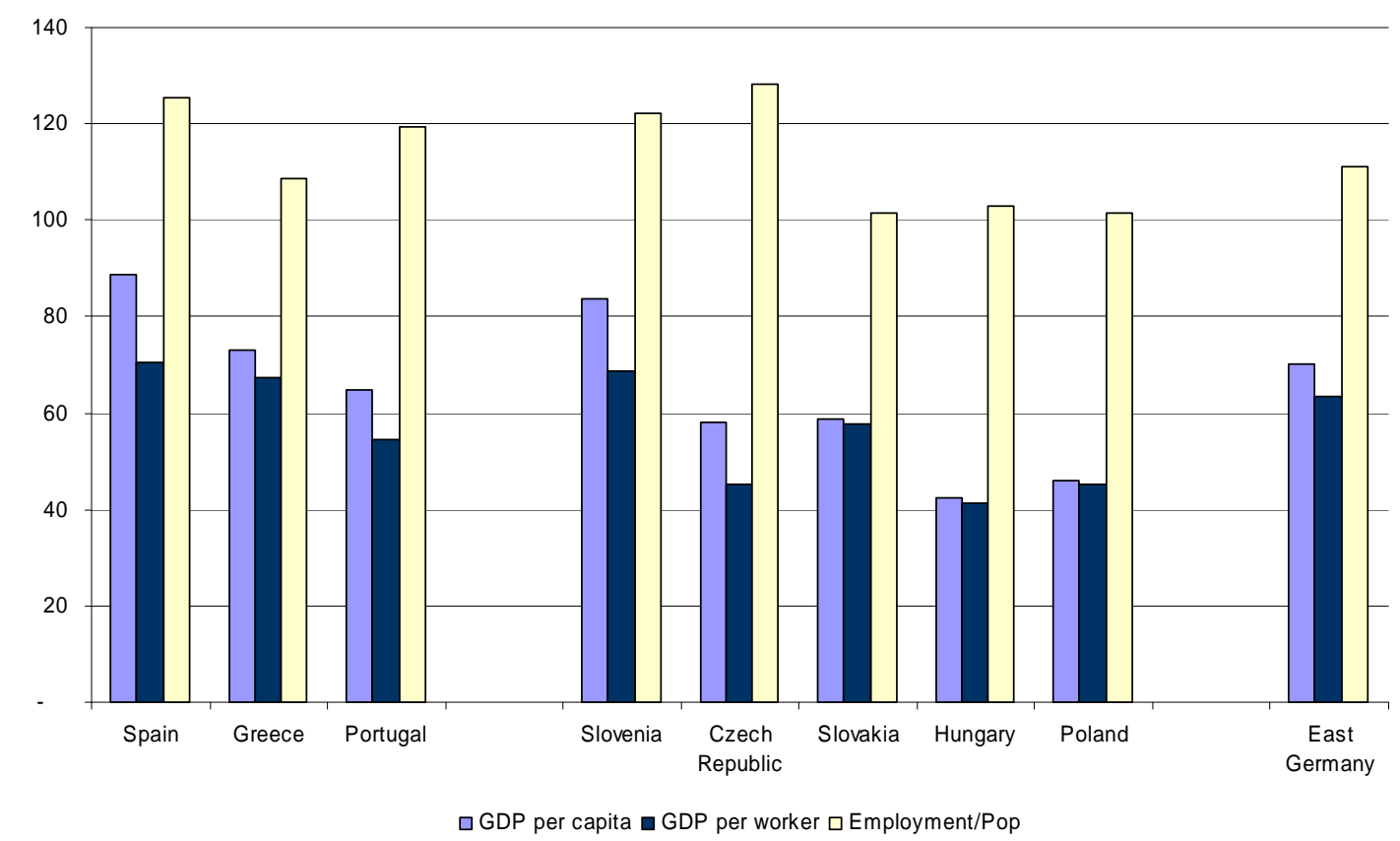

Sources: The Conference Board Total Economy Database, January 2010, http://www.conferenceboard.org/economics/database.cfm, Volkswirtschaftliche Gesamtrechnungen der Länder (2009)

The historical precedents of rapid catch-up in Europe undoubtedly influenced expectations about the post-transition experience. Closer examination of the Southern and Eastern episodes highlighted the initially greater gap (to France) for most of the transition economies. Measured against the Southern catch-up episodes and against its transition comparators, East Germany's performance was neither exceptionally good nor bad.

\section{What was the binding constraint on catch-up?}

I use the framework of growth diagnostics proposed by Hausmann, Rodrik and Velasco (2006) to analyze the reasons for slow catch up in transition. The starting point for growth diagnostics is a standard endogenous growth model and the framework is illustrated in a decision tree diagram (Fig. 6). The aim is to help a policy maker identify priorities for allocating scarce financial resources and attention by pinning down the binding constraint on growth from among many possibilities. The 
initial distinction is between a situation in which the growth of private investment and entrepreneurship are inhibited by (a) too low a rate of return on private investment and (b) too high a cost of finance. If there is evidence of an abundance of profitable projects but the high cost of finance prevents them from being undertaken, the question arises of whether it is poor access to international finance or poor local finance that is at fault. In the case of poor local finance, this could be due to weak intermediation or because of low savings.

In the left hand side of the tree (Fig. 6), the availability of finance is not binding rather, it is the low rate of return on investment that is the problem. This could be because of the effect of poor complementary factors (such as unfavourable geography, inadequate physical infrastructure or weak human capital) in reducing expected private returns. Alternatively, government failures could be responsible by raising micro or macroeconomic risk. The final branch points to market failures and the associated lack of good projects.

Figure 6. Growth Diagnostics: What is the Binding Constraint on Growth where Private Investment and Entrepreneurship are Low?

\section{Growth depends on (rate of return - real interest rate)}

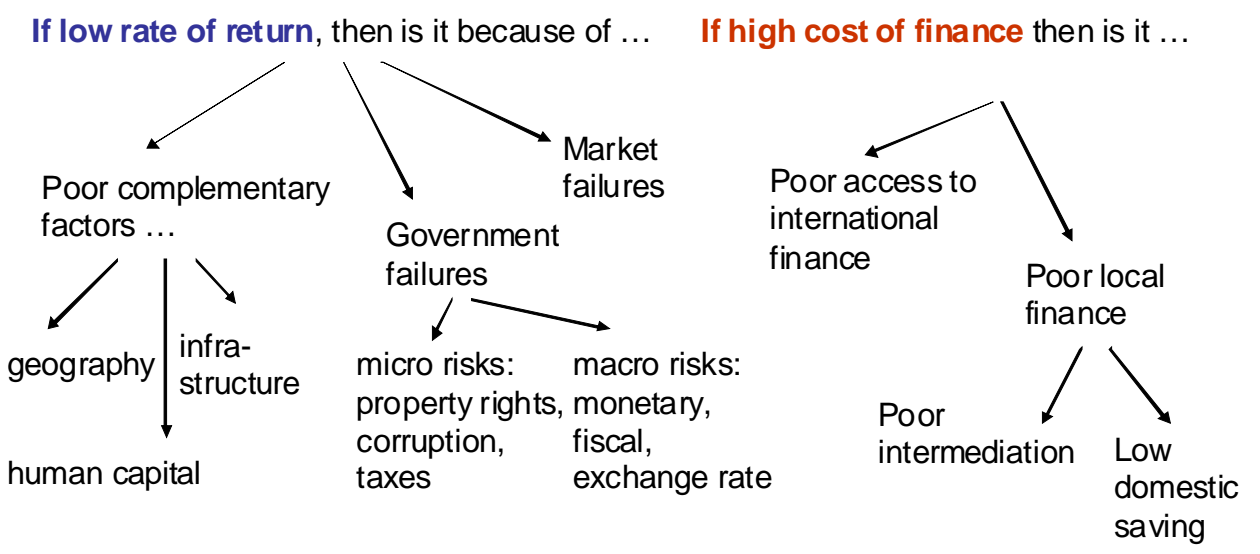

Source: Adapted from Hausmann et al. (2006)

Although convergence of the transition economies has been disappointing, it is difficult to argue that this was because of lack of access to finance. A striking feature of transition was that unlike typical developing countries, the CEEC transition economies defied the so-called Lucas Paradox: capital flowed to these economies and 
they did not have repeated balance of payments crises (Prasad et al. 2007, IMF WEO 2009, Lane and Milesi-Ferretti, 2007). This suggests that the binding constraint was not poor access to international finance (Coricelli et al. 2008). Moreover international banks largely took over local banking networks, providing expertise and access to international capital markets (Clarke et al. 2003, Clarke et al. 2006). For the CEECs and East Germany, it seems reasonable to presume that we are in the left hand part of the decision tree: the rate of return, not the cost of or access to finance was the problem.

We can also rule out poor complementary factors - these countries were situated contiguous to the European Union market and a positive legacy of communism was to leave levels of human capital and skills higher than those of the market economy benchmark at similar levels of GDP per capita (Gros and Suhrke 2000, World Bank 2006). The physical infrastructure legacy was also positive relative to countries at comparable levels of GDP per capita (Mitra et al. 2010, chapter 5).

A large research literature emerged in the past decade arguing that it was institutional weakness (government failure) that hampered the rapid catch up of the CEECs (see e.g. Rodrik, 2006). The emphasis in the Washington Consensus was on macroeconomic policy failures as the core problem of development but the absence of rapid growth following the implementation of orthodox macroeconomic policies in transition forced attention on to the weakness of market economy institutions. As transition proceeded, it became clear that abolishing planning, establishing macroeconomic stability, and liberalizing trade and prices were insufficient to generate a functioning market economy. Effective legal systems, reliable and predictable tax and customs administration, norms and rules to control corruption, and so on were not created overnight. New owners had to be found for large enterprises and it became clear that privatization in the absence of adequate corporate governance failed to lift the performance of privatized enterprises above that of state owned ones (Estrin et al. 2009). Foreign owned firms performed notably better than those privatized to domestic owners.

If government failure or institutional weakness was a likely cause of slow catch-up in the CEECs, it was prima facie less plausible as a binding constraint in East Germany. 
The prima facie argument rested on the transfer of West German institutions to East Germany. Nevertheless there are two caveats to dismissing this as a binding constraint. The first is that institutions are not only 'rules on the books' but also norms, and recreating market economy norms was not immediate even in East Germany. Alesina and Fuchs-Schuendeln (2007) showed that East Germans continued to have different attitudes to state intervention than West Germans, and argued that such differences were likely to persist for another generation.

The second caveat relates to the possible 'mismatch' of specifically West German as compared with generic - market institutions with the needs of the transitional East German economy (e.g. Carlin 1998). The core export-oriented sector of the West German economy is characterized by a number of specialized institutional arrangements involving among others unions, employers' associations, works councils, the commitment to transferable skills training by companies, technology transfer institutions, and various state-, quasi-state and private organizations at Federal, Land and local level. For example, it is argued that unions, employers' associations and works councils play an important role in delivering wage compression and employer commitment to training that lie behind the high-skills ‘equilibrium' of the West German core economy (e.g. Hall and Soskice, 2001, Acemoglu and Pischke, 1998, Dustmann and Schoenberg, 2008).

The most well-known example of institutional transfer to East Germany was the recruitment of East German workers by West German unions and the participation of the Treuhandanstalt in wage-setting. Combined with the extension of social security entitlements, this placed a high floor under the wage. This rendered unprofitable much of the capital stock, producing the rapid deindustrialization of East Germany and raised the bar for the required productivity level of new projects if they were to be profitable. Once West German companies rapidly revised downwards their initial expectations of accessing buoyant markets in the former Soviet Union via the expansion of production facilities in East Germany, it proved impossible to replicate the West German core economy and its institutional context in the new Bundesländer. East Germany was left with the cost burden of the wage-setting and social security system without its micro-institutional benefits (Carlin 1998, Figure 1). 
The federal government was forced to step in to deal with problems arising from the failure of the West German model to operate in the East (Jacoby, 2005). Combined with the associated fiscal burdens, this led to important changes in policy and institutions in the Federal Republic as a whole, culminating in the Hartz IV welfare reforms. Nevertheless, the export-oriented core of the West German economy retained its self-organizing capacity (as reflected in the substantial restructuring and real depreciation achieved over the post 2000 period, Carlin and Soskice, 2008). Yet in spite of the formal transfer of institutions, it did not extend its scale through replication in East Germany. The experience of East Germany over the past two decades was one of institutional adaptation - most obviously in the low membership of East German companies in employers' associations and the associated limited coverage of collective wage agreements in East Germany (Paqué, 2009, pp. 149-55).

In spite of these caveats, institutional quality, in the sense of the credibility and efficiency of the core market economy institutions of a functioning legal system, control of crime and corruption, and the efficient administration of taxes, customs, were established quickly in East Germany. We are therefore led to turn to the final branch in the diagnostic tree diagram - market failures - in order to pin down the binding constraint on East German growth.

Hausmann et al. explained the 'market failure' problem in a less advanced economy as follows: "the development process is largely about structural change: it can be characterized as one in which an economy finds out - self-discovers - what it can be good at, out of the many products and processes that already exist.” (p. 18). In East Germany's case, this problem was compounded because the floor on real wages set by the political settlement (including the need to prevent mass migration to West Germany) meant it needed to 'self-discover' at a point much closer to the technology frontier than is the case for a typical developing or transition country. New ideas for tradeables were required in order to replace the old activities rendered unprofitable by openness to international competition. Opening up to international trade and capital flows does not automatically generate knowledge of profitable niches. Self-discovery is inhibited by learning and coordination externalities. In the core of the West German economy, a complex institutional matrix promotes the spillover of technological and 
marketing information and the coordination of lumpy upstream and downstream investments. But as noted above, this was not reproduced in the East.

Moreover, East Germany faced problems of self-discovery even in non-tradeables. Normally in the sheltered sector, domestic firms have the opportunity to benefit from monopolistic innovation rents. But even in non-tradeables, the first-mover advantages for local suppliers in East Germany were often taken by West German firms - East German firms immediately faced 'foreign' suppliers and hence lower profits from ‘innovation' in such markets.

The literature on East German development has addressed the presence of 'market failures' of these kinds that are related to informational and coordination externalities - as opposed to macroeconomic, infrastructural or institutional failures - in a number of different ways. As an example, Uhlig (2008) modeled East Germany as trapped in a low level equilibrium characterized by low productivity and out-migration due to the absence of networks. Uhlig's model is interesting because the existence of network externalities in a search model produces multiple equilibria in the absence of labour market distortions (such as those emphasized by Merkl and Snower, 2008). He assumed that firms are more productive when they join a 'labour sharing network' and that the probability of joining a network decreases as the ratio of non-networked to networked firms rises. Workers move in response to differences in opportunities offered in networked and non-networked regions: persistently low productivity and out-migration therefore go hand-in-hand. Uhlig's model formalizes the situation in which productivity rises when worker-firm pairs are part of a network to which they contribute a specialized component. Specialization raises productivity and networks facilitate this.

Rosenfeld et al.'s $(2004,2007)$ empirical characterization of spatially concentrated industries in East Germany showed, consistent with Uhlig's predictions, that such clusters with network and innovative characteristics were relatively rare. A number of methods of discovery appear to have been relevant for East Germany: those based on historical patterns of specialization reaching back before the planning period (such as the case of Zeiss discussed by Kogut and Zander, 2000), identification of potential in core businesses through the Treuhand process, and more traditional industrial policy 
where the coordination problem of forward and backward linkages was solved by massive state intervention (most notably in the chemical industry complex, Infraleuna, Paqué, 2009, pp.96-99).

To summarize, the purpose of the diagnostic decision tree is to discard candidates for the most binding constraint on growth - because the constraint that remains is the one that should receive most attention from policy makers. In East Germany, a case can be made that the binding constraint on growth was the low rate of return arising from the inadequate supply of 'good projects'. The problem was not a lack of savings or access to finance; not inefficient or corrupt institutions, or weakness of complementary factors. An initially overvalued regional real exchange rate exacerbated East Germany's problems but given the political constraints set by unification, the solution required dealing with the market failures inhibiting the development on a sufficient scale of globally competitive activities in East Germany.

\section{What is the scale of the problem still faced by East Germany? The evolution of the 'export base'}

Transition economies left the planning era with oversized industrial sectors relative to a market economy benchmark. East Germany's rapid deindustrialization following unification led it to overshoot the market economy benchmark. One reflection of this is its very low employment rate in industry. Figure 7 compares employment rates in industry (excluding construction) in East Germany with a number of transition economies, and with West Germany. 
Figure 7. Employment Rates in Industry (excluding construction) per cent of working age population, 2007

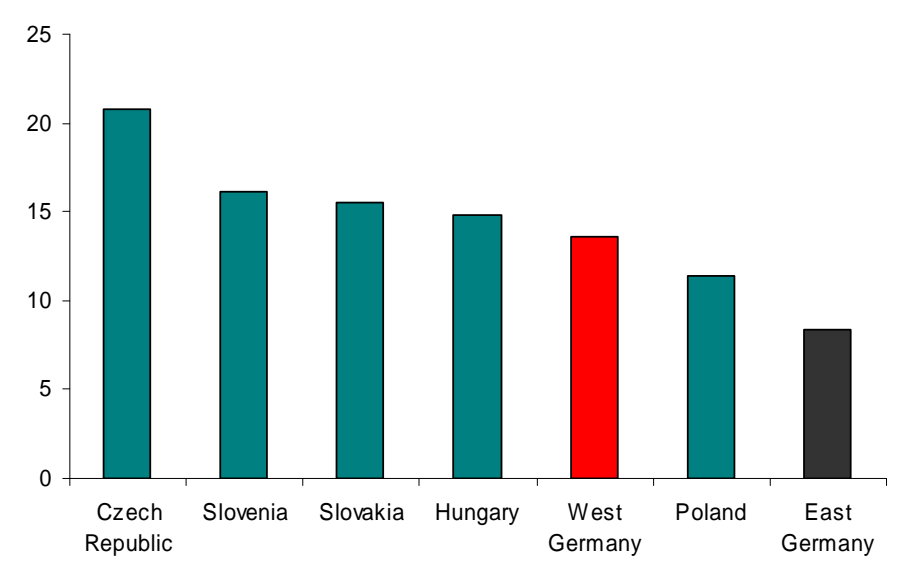

Sources: ILO LABORSTA CE tables and St. Bundesamt VGR der Laender; Definition: ISIC 3 $\mathrm{C}+\mathrm{D}+\mathrm{E}$

There is a scarcity in East Germany of what we can refer to as 'export-base' jobs.

These are jobs engaged directly or indirectly in the production of goods and services sold beyond the region. A lagging region lacks sufficient jobs of this kind and is characterized by dependence on the central government to support living standards. Support arises from benefit payments and from the financing of government employment, where pay scales are set nationally. In principle there are two ways to eliminate such regional economic weakness:

(a) potential workers move to the other region, i.e. to West Germany and / or (b) new jobs are created in East Germany.

For political reasons, it is implausible that all the adjustment would take place through the movement of population, and for economic reasons, it is infeasible for all the adjustment to take place through the creation of new export base jobs. A satisfactory adjustment path would therefore be likely to involve both processes (Rowthorn, 2000). What is an unsatisfactory outcome? An unsatisfactory outcome is a Mezzogiorno scenario where excess population remains in the lagging region and local economic development is too weak to absorb it: productivity fails to converge and living standards are sustained by federal transfers. After a brief burst of adjustment in the 1960s, the Italian south was characterized by the Mezzogiorno scenario (Boltho et al. 1997). 
Using regional data for Germany, it is possible to make a crude calculation of the evolution of employment in tradeables, private non-tradeables and the government (i.e. non-market non-tradeable) sector. Employment in tradeables was defined by employment in agriculture, mining, and manufacturing plus "extra" employment in finance and business services. In each year, the region in Germany with the lowest ratio of employment in finance and business services to population across all regions was used to define the share of employment in this sector that could be viewed as non-tradeable, i.e. producing services required to support the local population. The remainder of employment in finance and business services in each region was defined as part of the 'tradeable' sector (Rowthorn 2000 used a similar procedure to analyze the UK). Employment in the government sector was defined as that in 'public administration, defence and social security'. The results highlight the differences in the deployment of resources in East and West Germany - the employment rate deficit of East Germany is large in tradeables at some 8 percentage points. The employment rate in private non-tradeables is also markedly lower in East Germany.

Using 1991 as the base year, Fig. 8 plots the evolution of population of working age and employment in East Germany relative to Germany as a whole. The population of working age in East Germany fell by $5 \%$ relative to Germany over the period. The chart makes clear that employment fell by much more. Following the end of the construction boom (reflected in the bulge in East Germany's share of employment in private non-tradeables), relative employment growth in both the government and in private non-tradeables evolved in line with relative population. This is what would be expected since employment in non-tradeables serves the local population. The normalization of the East German economy would involve bringing the employment in tradeables and population lines closer together: either by population draining from East Germany and / or by rising employment in tradeables, which would tend to stabilize the working age population and the associated non-tradeables employment. Given the loss of 'export base' jobs in the initial phase of the East German transition, this remains a substantial task. Nevertheless, Fig. 8 indicates that both adjustment processes discussed above were present in East Germany from around the year 2000. 
Figure 8. Trends in East Germany relative to Germany as a whole: Population of working age, Employment in Tradeables, in Non-Tradeables and in Government, 1991-2007

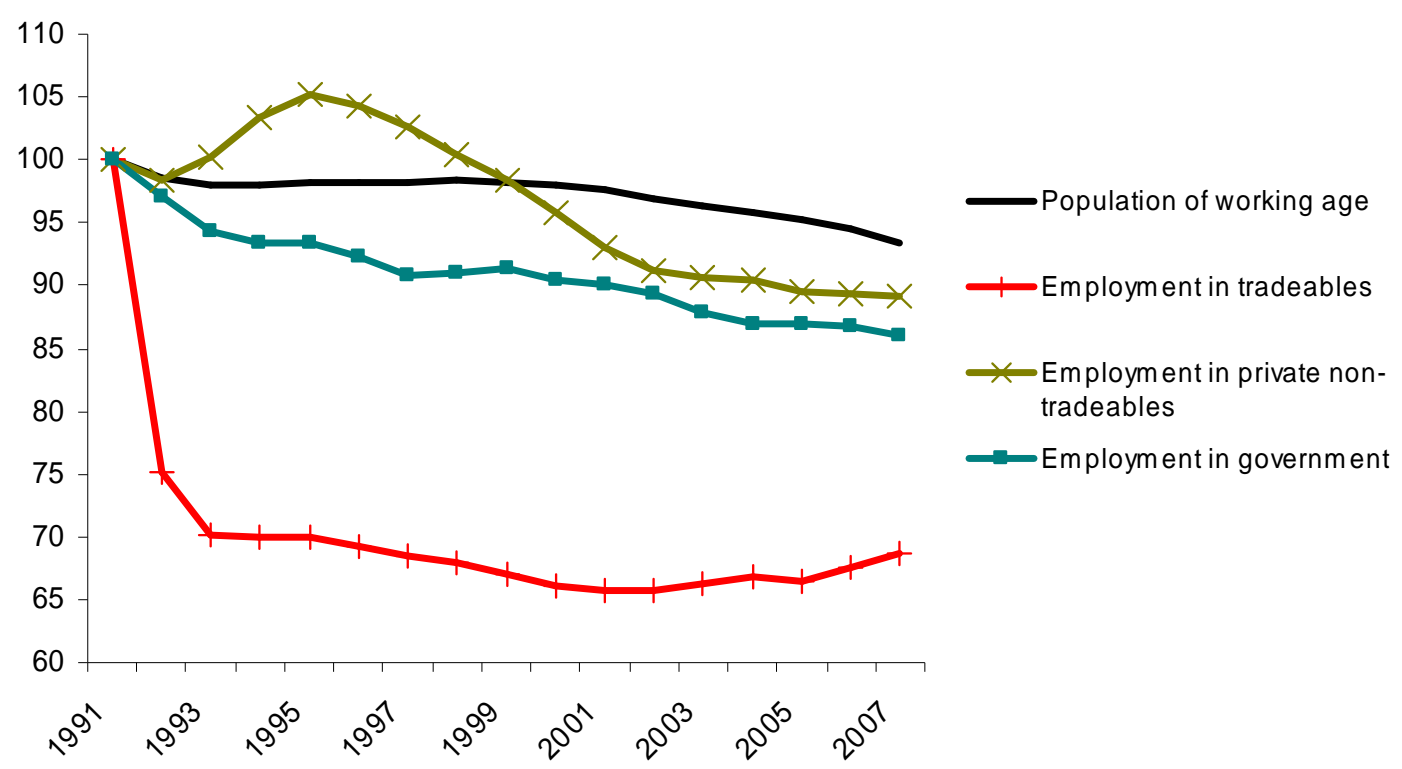

Source: Calculated from data in Volkswirtschaftliche Gesamtrechnungen der Länder (2009)

Fig. 9 presents the employment rates in East and West Germany for tradeables and the two components of non-tradeables. In West Germany the rising overall employment rate was driven by private non-tradeables and a steady rise in the employment rate in the government sector. The upturn in East Germany's employment rate over recent years was the result of the recovery of the employment rate in private non-tradeables to a level similar to the peak achieved during the post-unification construction boom, the stabilization and slight upturn in tradeables and the continued rise in the employment rate in the government sector. 
Figure 9. Trends in Employment Rates (per cent of population of working age) in East and West Germany: Tradeables, Non-Tradeables and Government, 1991-2007

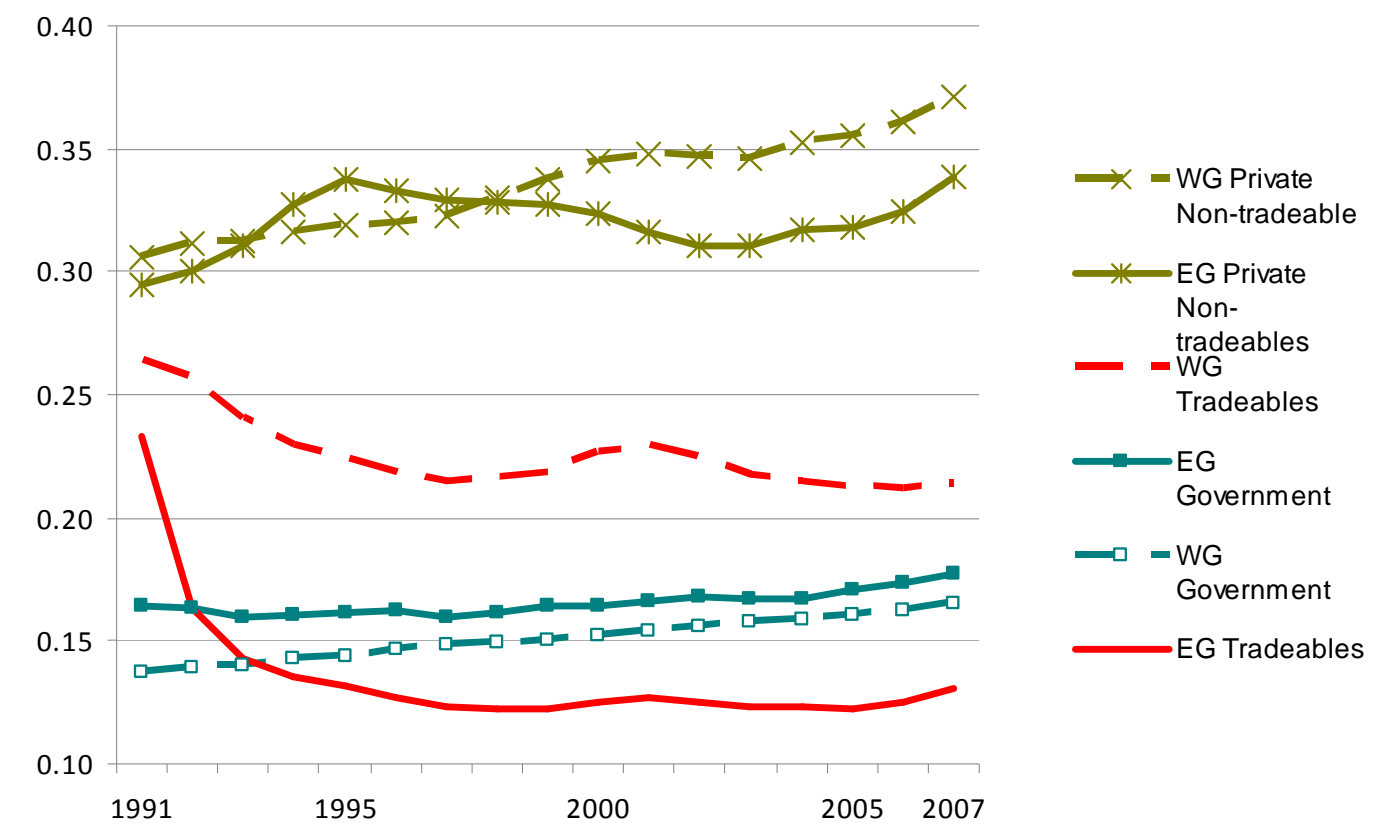

Source: Calculated from data in Volkswirtschaftliche Gesamtrechnungen der Länder (2009)

The final exercise compares developments among the East German Länder. Fig. 10 shows the ratio of the employment rate by sector in each East German Land to the average across West German Länder. The clearest contribution to the amelioration of the regional problem can be seen in Thüringen and Sachsen with employment rates in tradeables rising toward the West German norm. There is some sign of this pattern in Sachsen Anhalt as well. Stabilization of the non-tradeables employment rates at a level somewhat below the West German rate is characteristic of most of the regions. However, Mecklenburg-Vorpommern appears to have the emerging characteristics of a Mezzogiorno region with little sign of closure of the huge employment rate gap in tradeables. It would appear that emigration is too weak to remove the surplus labour and local economic development is too weak to absorb the 'stayers'. The high employment rate in the government sector in this region is consistent with the decline of the region and its dependence on transfers. 
Figure 10. Ratios of Employment Rates (per cent of population of working age):

Eastern Land to the average across West German Länder, 1991-2007
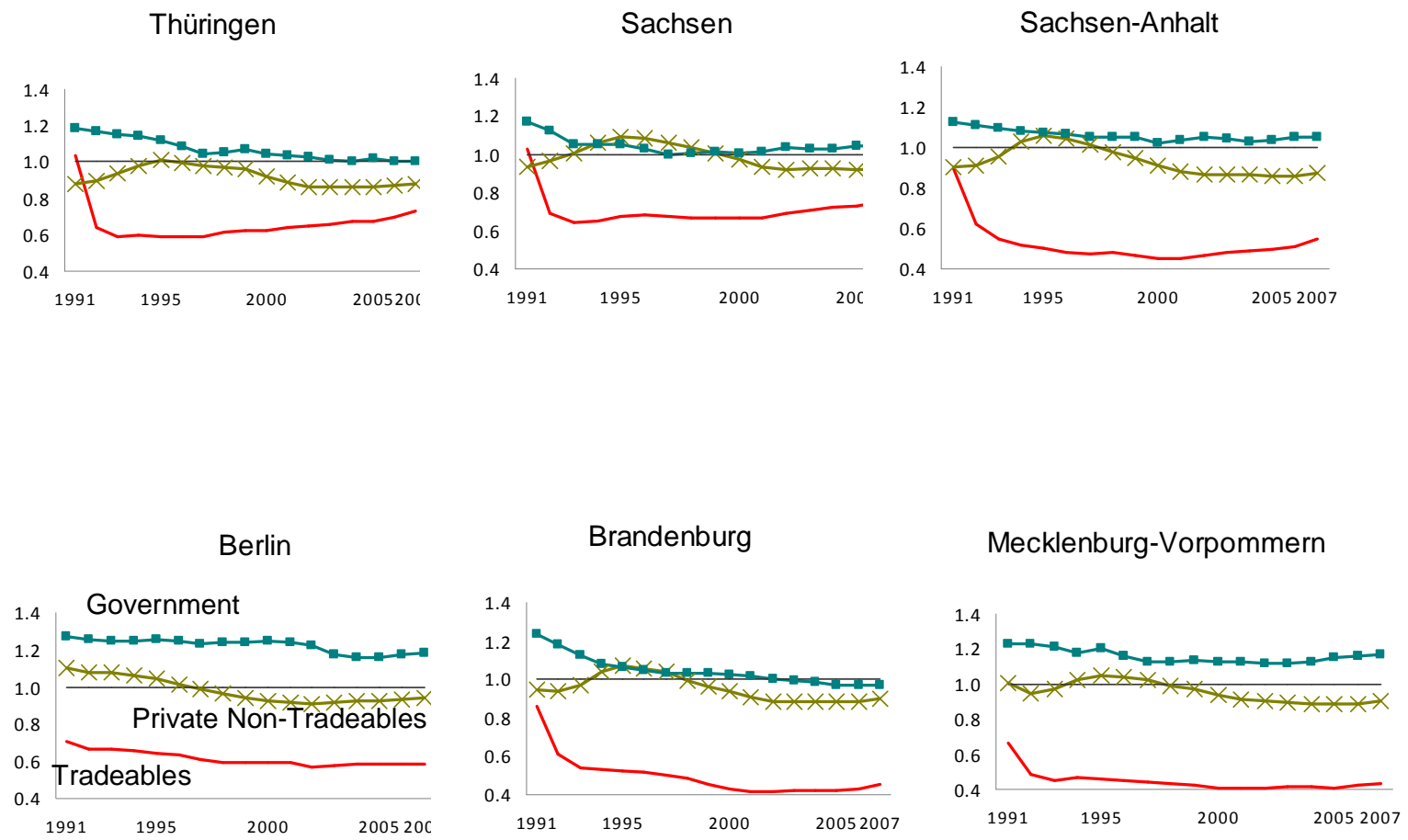

Source: Calculated from data in Volkswirtschaftliche Gesamtrechnungen der Länder (2009)

Although the gaps in tradeables employment rates remain large, the achievements of East German development are tangible and suggest that East Germany as a whole is not trapped in a Mezzogiorno scenario. In the absence of policy instruments directly able to remove the market failures inhibiting the development of East Germany's export base, real depreciation is beneficial. The decoupling of wage-setting in East Germany from the West allowed East Germany to improve its cost competitiveness throughout the unification period. From 1999, unit labour costs in industry were below those in the West - leaving East Germany with a cost advantage of about $15 \%$ in 2006.

Fig. 11 highlights the contemporaneous correlation between the narrowing of East Germany's 'external balance' with West Germany and improvement in its competitiveness vis-à-vis West Germany. The full effects of the improvement in competitiveness may not be reflected in employment and external balance since international evidence suggests that there is a considerable lag - of up to six years - 
before the full effects on export market shares of improved cost competitiveness are reaped (Carlin et al. 2001).

Fig. 11. Relative unit labour costs in industry EG:WG and East Germany's 'external balance' as \% of GDP, 1991-2006

Relative unit labour costs

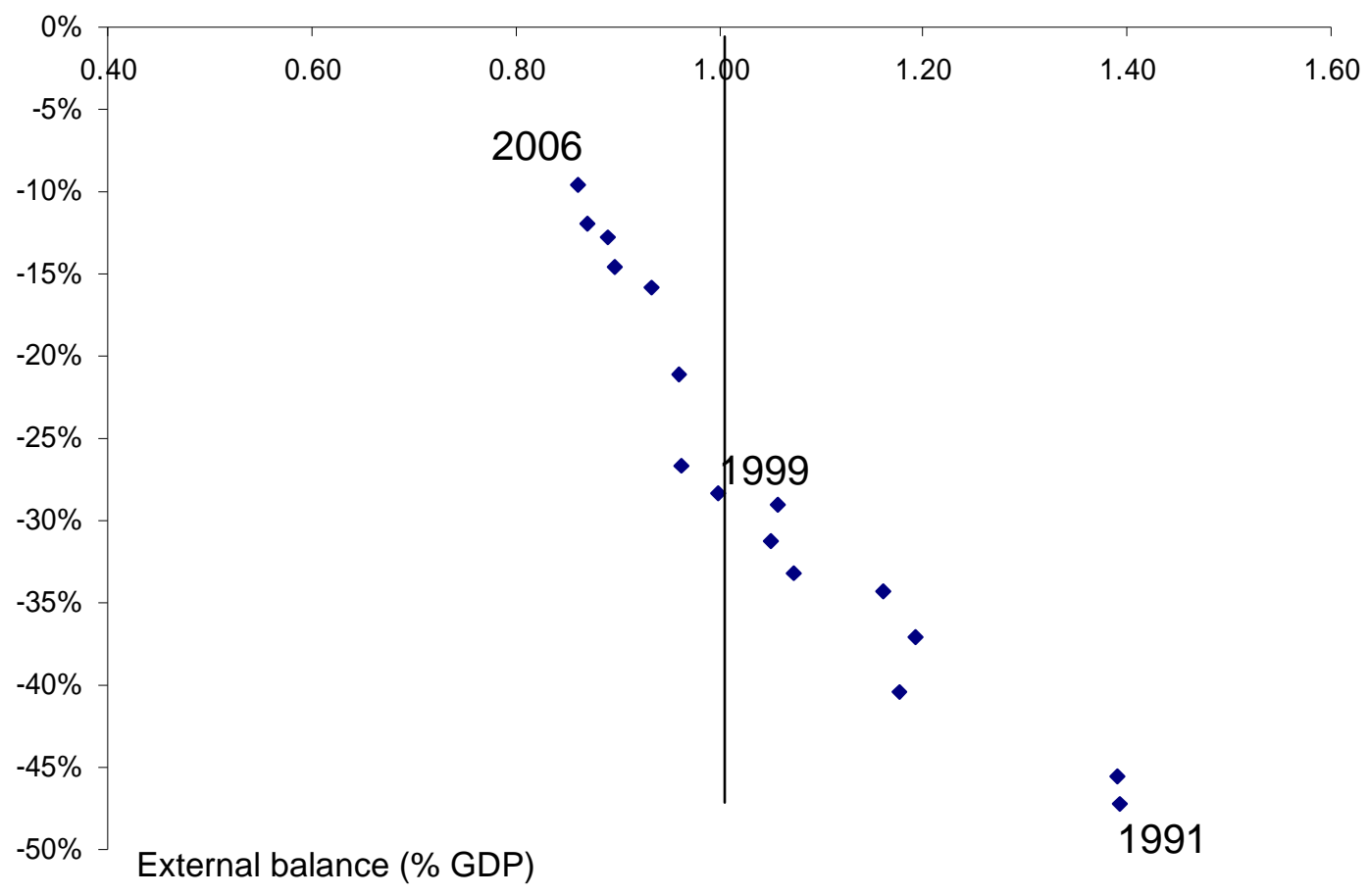

Source: Calculated from data in Volkswirtschaftliche Gesamtrechnungen der Länder (2009)

Buch and Toubal (2009) provide evidence of persistent differences between East and West Germany in their integration in international trade. They showed that East German Länder trade much less with the rest of the world than West German ones, had fewer parents of multinational companies than was the case in the West and a lower share of inward FDI. Buch and Toubal showed that there was only slow convergence of East to West German levels. During the period 1992 to 2004 in which West German Länder became markedly more open with a rise in the share of trade (imports plus exports) in GDP from 37\% to 51\%, East Germany's openness increased from $16 \%$ to $20 \%$ (leaving it only just over half as open as was West Germany in 1992). The methodology is well-designed to show a causal effect from lower openness to lower GDP per capita, highlighting the consequences of East Germany's limited success in discovering its sources of comparative advantage. 
Figure 12 shows that nominal wage restraint and more rapid hourly productivity growth both contributed to East Germany's improved competitiveness in manufacturing since 2000. It is productivity catch-up that made the greater contribution. The chart also makes clear that productivity improvement was accompanied by the stabilization of hours worked in manufacturing in East Germany. Money wage growth was close to that in West German manufacturing - reflecting the outcome in wage-setting of the conflicting pressures of a persistently weaker labour market in East Germany and the much more rapid growth of relative productivity.

Figure 12. East and West German Productivity, Labour Compensation and Hours worked in Manufacturing, 2000-2008

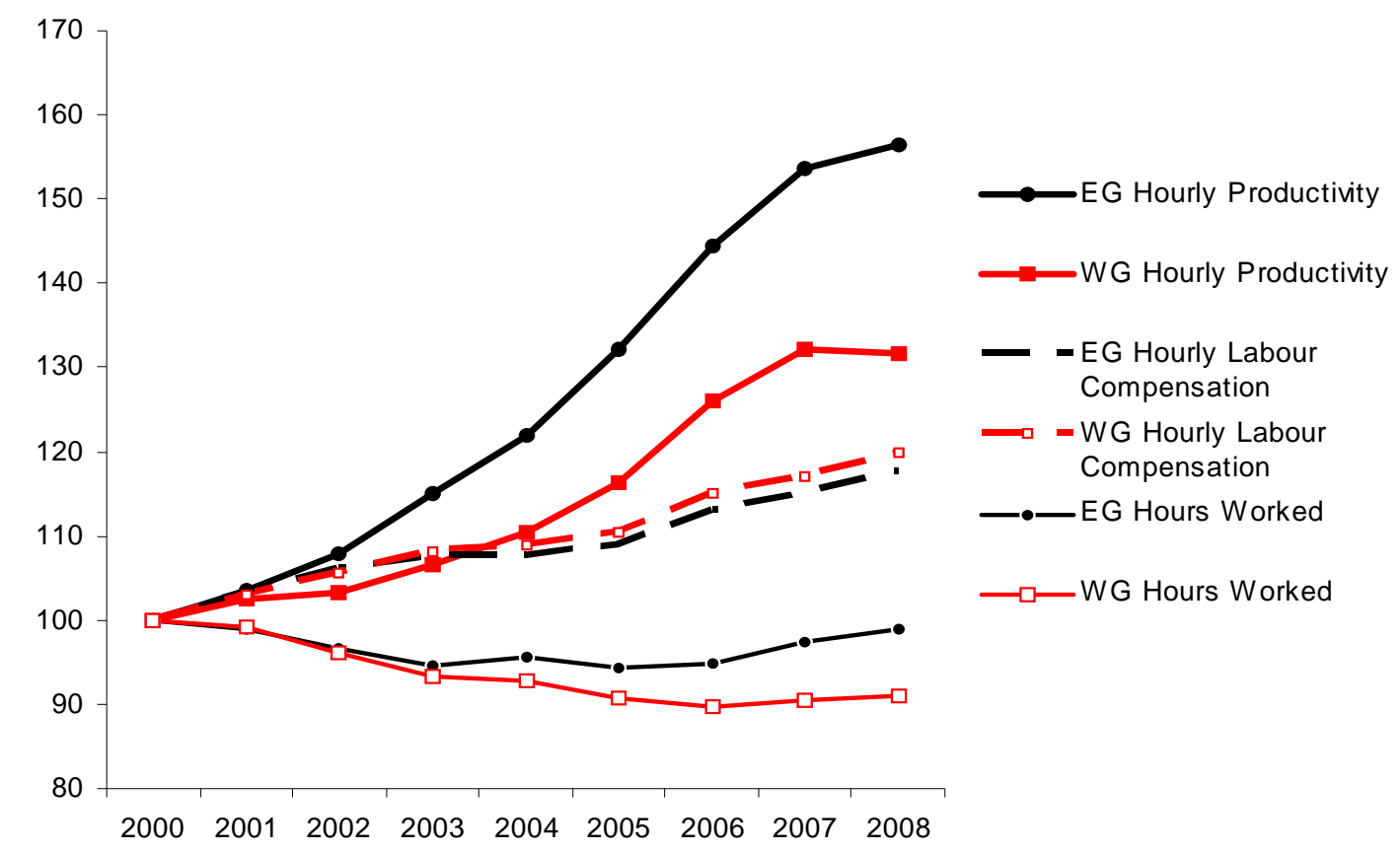

Source: Calculated from data in Volkswirtschaftliche Gesamtrechnungen der Länder (2009)

The success of East Germany in achieving a substantial real depreciation vis-à-vis West Germany is all the more notable in the light of Germany's improved competitiveness versus other members of the eurozone since 1999. Fig. 13 shows the evolution of real exchange rates among the EU27 countries. Germany's real depreciation is evident both as compared with southern European eurozone members in the left panel and as compared with central and east European transition economies in the right panel. 
Figure 13. Real exchange rates (EU27) measured by relative unit labour costs in manufacturing, 1999-2008; 1999=100
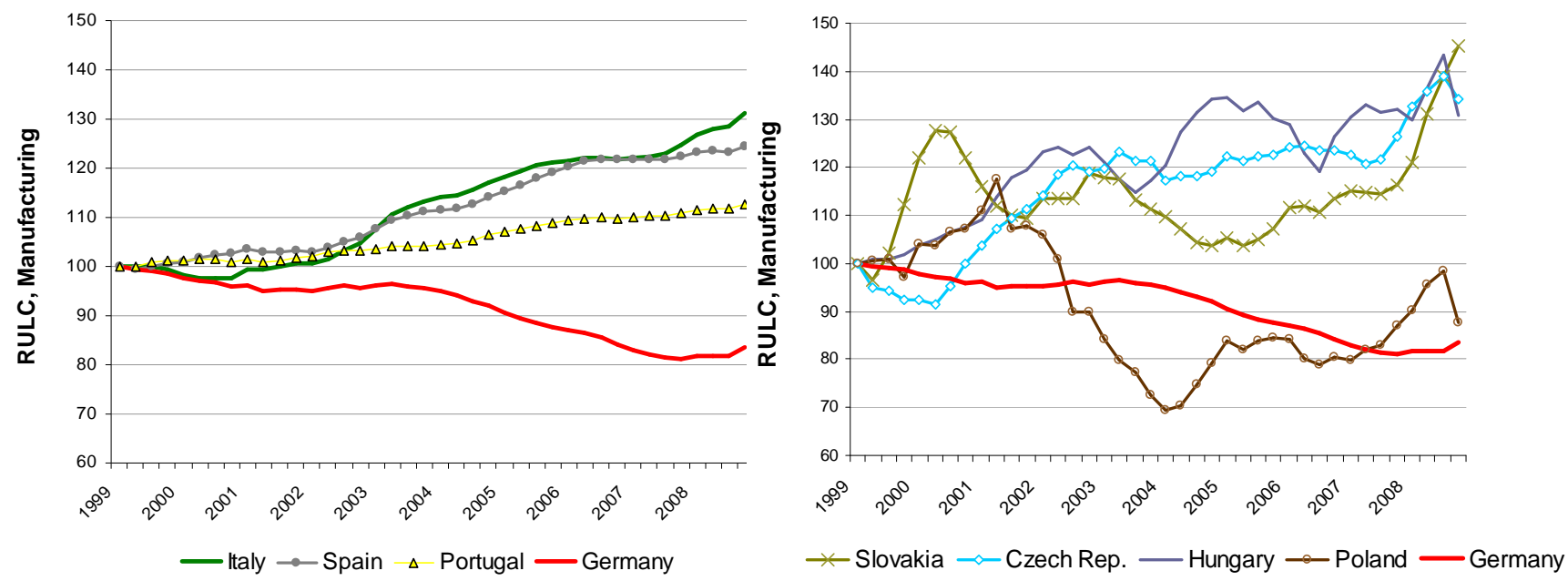

Source: Eurostat (2010). Quarterly Real Effective Exchange Rates.

The difficulty of achieving lower unit cost increases without the help of a nominal depreciation is evident in the cumulative competitiveness gaps (and associated widening of trade deficits) that now exist in a number of eurozone countries. The adaptation of the wage-setting system and productivity improvements achieved in East Germany are a notable success.

Fig. 14 makes a direct comparison between the level of nominal wages, productivity and unit labour costs (in euros) in industry in East Germany in 1995 and 2004 with those in the Czech Republic, Hungary and West Germany. The lower panel of Fig. 14 highlights very sharply the extent to which productivity in East Germany has converged toward that in West Germany - and the size of the gap to the Czech Republic and Hungary that remains. The purchasing power parity-based comparisons in Section 2 are relevant for the analysis of convergence in living standards but the comparisons shown in Fig. 14 capture the continuing gaps in production techniques. Because of the degree of overvaluation that came with unification, the industrial sector in East Germany shrank. Only high productivity activities could survive. As the upper panel shows, East Germany's competitive disadvantage in 1995 is clear: its unit labour costs were substantially higher than elsewhere. By 2004, as noted above, its unit labour costs were below those of West Germany and the competitive disadvantage vis-à-vis the Czech Republic and Hungary had also shrunk. The lower 
panel shows that this was due both to lower money wage growth and more rapid productivity growth. Unfortunately more recent comparable data are not available but it is clear that given the deterioration in relative unit labour costs of the Czech Republic and Hungary against Germany as a whole after 2004 (Fig. 13), East Germany's competitive disadvantage would have narrowed yet further by 2008 .

Figure 14. Comparative costs in industry (euros): East Germany, West Germany, Czech Republic and Hungary, 1995 and 2004.
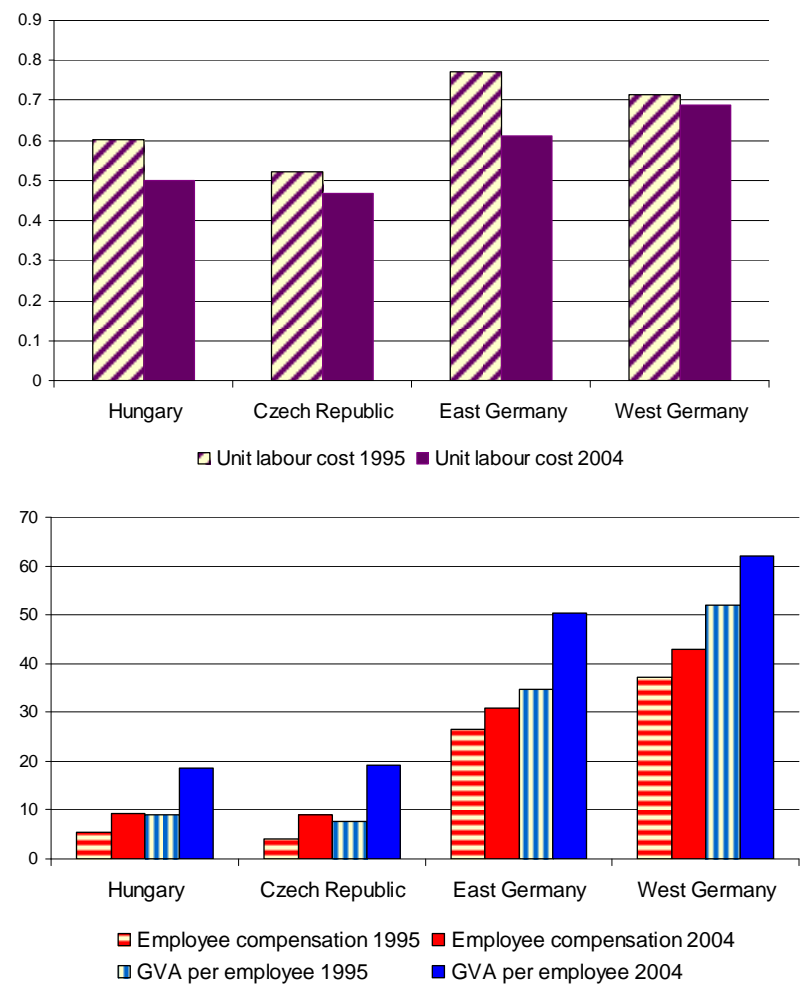

Source: Eurostat/New Cronos database (2010) Regional economic accounts/Branch accounts

\section{Conclusions}

East Germany's experience of transition highlights the limited extent to which good institutions alone can overcome 40 years of missing market experience, especially during a period of increasingly integrated global markets. The East German case brings to the fore the problem of finding a niche in the international division of labour. However, there are signs of slow improvement in East German performance. For the region as a whole, it does not seem that the Mezzogiorno scenario is an appropriate characterization.

Setting East Germany's performance within a broader context highlighted the contrast between its success in raising competitiveness and the erosion of competitiveness 
among a number of southern eurozone members. However, the speed of catch-up of East Germany is very slow and its continuation depends on the steady growth of its small poles of tradeables success. Given the evidence that agglomeration and networks are important, well-designed industrial policy to foster investment and job creation in the nodes of development that have established themselves is more likely to be successful than the application of 'watering can' support to the region as a whole.

Finally, East German catch up would be assisted by a more balanced pattern of growth in West Germany. A shift toward growth less reliant on net exports in West Germany and associated with stronger growth of real wages and consumption there would help reduce tensions and constraints on growth in the eurozone (where $40 \%$ of Germany's exports are sold). Given the decoupling of East Germany's wage-setting system, the region could gain in such a scenario from a further boost to its competitiveness and from more buoyant growth of markets in Germany and in the eurozone more broadly. 


\section{References}

Acemoglu, D. and Pischke, J.S. (1998). 'Why do firms train? Theory and Evidence' Quarterly Journal of Economics, 112, 79-119.

Alesina, A. and N. Fuchs-Schuendeln (2007) 'Good-bye Lenin (or Not?): The effect of communism on people's preferences' American Economic Review 97, 4, 1507-1528.

Arbeitskreis 'Volkswirtschaftliche Gesamtrechnungen der Länder' im Auftrag der Statistischen Ämter der 16 Bundesländer, des Statistischen Bundesamtes und des Bürgeramtes, Statistik und Wahlen, Frankfurt a. M. Volkswirtschaftliche Gesamtrechnungen der Länder (2009).

Boltho, A., Carlin,W. and P. Scaramozzino (1997). 'Will East Germany become a new Mezzogiorno?', Journal of Comparative Economics. 24(3), 241-264.

Buch, C. and Toubal, F. (2008). 'Openness and growth: the long shadow of the Berlin Wall', Journal of Macroeconomics. 31, 409-422.

Carlin, W., 1998, 'The New East German Economy: Problems of Transition, Unification and Institutional Mismatch', German Politics, 7 (3), 14-32

Carlin, W., Glyn, A. and J. Van Reenen (2001). 'Export market performance of OECD economics: an empirical examination of the role of cost competitiveness', The Economic Journal. 111(468), 128-162.

Carlin, W. and Soskice, D., 2009, 'German economic performance: disentangling the role of supply-side reforms, macroeconomic policy and coordinated economy institutions', Socio-Economic Review, Volume: 7, Pages: 67-99

Cesar da Neves, J.L. (1996). 'Portuguese postwar growth: a global approach', in Crafts, N. and Toniolo, G. eds. (1996) Economic Growth in Europe since 1945 Cambridge University Press.

Clarke, G., R. Cull, M. Martínez Peria, and S. Sanchez (2003). 'Foreign bank entry: Experience, implications for developing countries and agenda for further research', World Bank Research Observer 18 (1) (2003), pp. 25-29.

Clarke, G., R. Cull, and M. Martínez Peria (2006). Foreign bank participation and access to credit across firms in developing countries, Journal of Comparative Economics 34, 774-795

The Conference Board and Groningen Growth and Development Centre, Total Economy Database, June 2009,http://www.conference-board.org/economics/; East Germany Conference Board data linked to Volkswirtschaftliche Gesamtrechnungen der Länder (2009)

Coricelli, F., B. Jazbec and I. Masten (2008), "Sources and Obstacles for Growth in Transition Economies: the Role of Credit", Festschrift in Honor of G. Calvo, MIT Press.

Denisova, I., Markus, E. and Zhuravskaya, E. (2010). 'What Russians think about transition?, Economics of Transition forthcoming.

Dustmann, C. and Schoenberg, U. (2008). 'Apprenticeship training and commitment to training provision', Draft. UCL.

Easterlin, R. (2009). 'Lost in transition: Life satisfaction on the road to capitalism', Journal of Economic Behavior and Organization, 71(2), 130-145.

Eichengreen, B. (2006). The European Economy Since 1945. Princeton, New Jersey. Princeton University Press.

Estrin, S., Hanousek, J. Kocenda, E. and J. Svejnar (2009). 'The effects of privatization and ownership in transition economies', Journal of Economic Literature. 47(3). 
Gros, D. and M. Suhrcke, (2000) Ten years after: What is special about transition countries, Aussenwirtschaft 56 (2000), 201-224.

Grosfeld, I. and Senik, S. (2009). 'The emerging aversion to inequality', Economics of Transition 18(1). 1-26.

Guriev, S. M. and Zhuravskaya, E. V. (2009). '(Un)happiness in transition', Journal of Economic Perspectives, 23, 143-168.

Hall, P. A. and D. Soskice, Eds. (2001). Varieties of Capitalism: the Institutional Foundations of Comparative Advantage, Oxford University Press Chapter 1.

Hausmann, R., Rodrik, D. and Velasco, A. (2006). 'Growth Diagnostics' in Finance and Development 43 (1). and in N. Serra and J. Stiglitz (ed.) (2008). The Washington Consensus Reconsidered: Towards a New Global Governance Oxford: OUP.

Jacoby, W. 2005. "Institutional Transfer: Can Semisovereignty be Transferred? The Political Economy of Eastern Germany." in Simon Green and William Patterson (eds), Governance in Germany: The Semisovereign State Revisited. New York: Cambridge University Press, pp. 21-45.

Kogut, B. and Zander, U. (2000). 'Did socialism fail to innovate? A natural experiment of the two Zeiss companies' American Sociological Review, 65(2), 169-190.

Kornai, J. (2006). 'The great transformation of Central Eastern Europe', Economics of Transition, 14, 207-244.

Lane, P. R. and G. M. Milesi-Ferretti (2007), "Capital Flows to Central and Eastern Europe”, Emerging Markets Review 8, 106 - 123.

Lehner, M. and M. Schnitzer (2008), "Entry of foreign banks and their impact on host countries", Journal of Comparative Economics, 36(3), 430-452.

Merkl, C. and Snower D. (2008). 'Escaping the unemployment trap: the case of East Germany'. Journal of Comparative Economics. 36(4), 542-556.

Mitra, P., Selowsky, M. and Zalduendo, J. (2010). Turmoil at Twenty World Bank.

Paqué, K-H. (2009). Die Bilanz: Eine wirtschaftliche Analyse der Deutschen Einheit. Hanser : München.

Prasad, E.S., Rajan, R.G. and Subramanian, A. (2007). 'Foreign capital and economic growth' Brookings Papers on Economic Activity 1, 153-209.

Prados de la Escosura, L. and Sanz, J. C. (1996). 'Growth and macroeconomic performance in Spain, 1939-93', in Crafts, N. and Toniolo, G. eds. (1996) Economic Growth in Europe since 1945 Cambridge University Press.

Rodrik, D. (2006) 'Goodbye Washington Consensus, Hello Washington Confusion?', Journal of Economic Literature 44, (4), 973-987

Rosenfeld, M., Franz, P., Gunther, J., Heimpold, G., Kawka, R. and Kronthaler, A. (2004) 'Innovative Kompetenz- felder, Produktionsnetzwerke und Branchenschwerpunkte der ostdeutschen Wirtschaft: Enbericht.' Unpublished Paper, 2004.

Rosenfeld, M., Franz, P. and G. Heimpold (2007). 'Economic clusters in East Germany: Evidence on the location and characteristics of spatially concentrated industries', Post-Communist Economies 19(1), 73-92.

Rowthorn, R. (2000). 'Kalecki Centenary Lecture: The political economy of full employment in modern Britain', Oxford Bulletin of Economics and Statistics. 62(2), 139-173.

Sanfey, P. and Teksoz, U. (2007). 'Does transition make you happy?'. Economics of Transition 15(4). 707-731. 
Uhlig, H., 2008, 'The Slow Decline of East Germany', Journal of Comparative Economics, 36(4), 517-541

World Bank (1996). From Plan to Market, World Bank, Washington, DC. 


\section{CESifo Working Paper Series}

for full list see www.cesifo-group.org/wp

(address: Poschingerstr. 5, 81679 Munich, Germany, office@cesifo.de)

3140 Lawrence M. Kahn, Labor Market Policy: A Comparative View on the Costs and Benefits of Labor Market Flexibility, July 2010

3141 Ben J. Heijdra, Jochen O. Mierau and Laurie S.M. Reijnders, The Tragedy of Annuitization, July 2010

3142 Erkki Koskela, Outsourcing Cost and Tax Progression under Nash Wage Bargaining with Flexible Outsourcing, July 2010

3143 Daniel Osberghaus and Christiane Reif, Total Costs and Budgetary Effects of Adaptation to Climate Change: An Assessment for the European Union, August 2010

3144 Philip E. Graves, Benefit-Cost Analysis of Environmental Projects: A Plethora of Systematic Biases, August 2010

3145 Sabrina Di Addario and Daniela Vuri, Entrepreneurship and Market Size. The Case of Young College Graduates in Italy, August 2010

3146 Shoshana Amyra Grossbard and Alfredo Marvăo Pereira, Will Women Save more than Men? A Theoretical Model of Savings and Marriage, August 2010

3147 Jarko Fidrmuc, Time-Varying Exchange Rate Basket in China from 2005 to 2009, August 2010

3148 Ilja Neustadt and Peter Zweifel, Is the Welfare State Sustainable? Experimental Evidence on Citizens' Preferences for Redistribution, August 2010

3149 Marcus Dittrich and Andreas Knabe, Wage and Employment Effects of Non-Binding Minimum Wages, August 2010

3150 Shutao Cao, Enchuan Shao and Pedro Silos, Fixed-Term and Permanent Employment Contracts: Theory and Evidence, August 2010

3151 Ludger Woessmann, Cross-Country Evidence on Teacher Performance Pay, August 2010

3152 Lorenzo C. G. Pozzi, Casper G. de Vries and Jorn Zenhorst, World Equity Premium Based Risk Aversion Estimates, August 2010

3153 Volker Grossmann, Thomas M. Steger and Timo Trimborn, Dynamically Optimal R\&D Subsidization, August 2010

3154 Alexander Haupt, Tim Krieger and Thomas Lange, A Note on Brain Gain and Brain Drain: Permanent Migration and Education Policy, August 2010 
3155 António Afonso and Christophe Rault, Long-run Determinants of Sovereign Yields, August 2010

3156 Franziska Tausch, Jan Potters and Arno Riedl, Preferences for Redistribution and Pensions. What can we Learn from Experiments?, August 2010

3157 Martin Kolmar and Andreas Wagener, Inefficient Group Organization as Optimal Adaption to Dominant Environments, August 2010

3158 Kai Carstensen, Klaus Wohlrabe and Christina Ziegler, Predictive Ability of Business Cycle Indicators under Test: A Case Study for the Euro Area Industrial Production, August 2010

3159 Horst Rottmann and Timo Wollmershäuser, A Micro Data Approach to the Identification of Credit Crunches, August 2010

3160 Philip E. Graves, Appropriate Fiscal Policy over the Business Cycle: Proper Stimulus Policies Can Work, August 2010

3161 Michael Binder and Marcel Bluhm, On the Conditional Effects of IMF Program Participation on Output Growth, August 2010

3162 Michael Binder, Qianying Chen, and Xuan Zhang, On the Effects of Monetary Policy Shocks on Exchange Rates, August 2010

3163 Felix J. Bierbrauer, On the Optimality of Optimal Income Taxation, August 2010

3164 Nikolaus Wolf, Europe's Great Depression - Coordination Failure after the First World War, September 2010

3165 Dan Kovenock and Brian Roberson, Conflicts with Multiple Battlefields, September 2010

3166 Jean-Pierre Ponssard and Catherine Thomas, Capacity Investment under Demand Uncertainty. An Empirical Study of the US Cement Industry, 1994-2006, September 2010

3167 Jørgen Juel Andersen, Jon H. Fiva and Gisle James Natvik, Voting when the Stakes are High, September 2010

3168 Michael Hoel, Is there a Green Paradox?, September 2010

3169 Scott Alan Carson, Nineteenth Century US African-American and White Female Statures: Insight from US Prison Records, September 2010

3170 Gil S. Epstein, Yosef Mealem and Shmuel Nitzan, Political Culture and Discrimination in Contests, September 2010

3171 Sara Fisher Ellison, Jeffrey Greenbaum and Wallace P. Mullin, Diversity, Social Goods Provision, and Performance in the Firm, September 2010 
3172 Silvia Dominguez-Martinez, Randolph Sloof and Ferdinand von Siemens, Monitoring your Friends, not your Foes: Strategic Ignorance and the Delegation of Real Authority, September 2010

3173 Marcus Dittrich and Beate Schirwitz, Union Membership and Employment Dynamics: A Note, September 2010

3174 Francesco Daveri, Paolo Manasse and Danila Serra, The Twin Effects of Globalization - Evidence from a Sample of Indian Manufacturing Firms, September 2010

3175 Florian Blöchl, Fabian J. Theis, Fernando Vega-Redondo and Eric O’N. Fisher, Which Sectors of a Modern Economy are most Central?, September 2010

3176 Dag Morten Dalen, Marilena Locatelli and Steinar Strøm, Longitudinal Analysis of Generic Substitution, September 2010

3177 Armin Falk, Stephan Meier and Christian Zehnder, Did we Overestimate the Role of Social Preferences? The Case of Self-Selected Student Samples, September 2010

3178 Christian Fahrholz and Cezary Wójcik, The Bail-Out! Positive Political Economics of Greek-type Crises in the EMU, September 2010

3179 Klaus Abberger and Wolfgang Nierhaus, The Ifo Business Cycle Clock: Circular Correlation with the Real GDP, September 2010

3180 Walter Krämer and Gerhard Arminger, "True Believers" or Numerical Terrorism at the Nuclear Power Plant, September 2010

3181 Bernard M.S. Van Praag, Dmitri Romanov and Ada Ferrer-i-Carbonell, Happiness and Financial Satisfaction in Israel. Effects of Religiosity, Ethnicity, and War, September 2010

3182 Dimitrios Koumparoulis and Paul De Grauwe, Public Capital, Employment and Productivity: An Empirical Investigation for Greece, September 2010

3183 John Whalley and Tanmaya Shekhar, The Rapidly Deepening India-China Economic Relationship, September 2010

3184 Andreas Schäfer and Thomas Steger, History, Expectations, and Public Policy: Economic Development in Eastern Germany, September 2010

3185 Thomas Eichner and Marco Runkel, Subsidizing Renewable Energy under Capital Mobility, September 2010

3186 Konstantinos Angelopoulos and James Malley, Fear of Model Misspecification and the Robustness Premium, September 2010

3187 Philip E. Graves, A Note on the Design of Experiments Involving Public Goods, September 2010 
3188 Glenn Ellison, How does the Market Use Citation Data? The Hirsch Index in Economics, September 2010

3189 Barbara Hanel and Regina T. Riphahn, The Employment of Mothers - Recent Developments and their Determinants in East and West Germany, September 2010

3190 Alexander Haupt and Silke Uebelmesser, Integration, Mobility, and Human Capital Formation, September 2010

3191 Vincenzo Galasso and Paola Profeta, When the State Mirrors the Family: The Design of Pension Systems, September 2010

3192 Stéphane Zuber and Geir B. Asheim, Justifying Social Discounting: The RankDiscounted Utilitarian Approach, September 2010

3193 Alexander Kemnitz, Educational Federalism and the Quality Effects of Tuition Fees, September 2010

3194 Claudia M. Buch, Sandra Eickmeier and Esteban Prieto, Macroeconomic Factors and Micro-Level Bank Risk, September 2010

3195 May Elsayyad and Kai A. Konrad, Fighting Multiple Tax Havens, September 2010

3196 Laszlo Goerke and Markus Pannenberg, Trade Union Membership and Dismissals, September 2010

3197 Ferdinand Mittermaier and Johannes Rincke, Do Countries Compensate Firms for International Wage Differentials?, September 2010

3198 John Boyd, Gianni De Nicoló and Abu M. Jalal, Bank Competition, Asset Allocations and Risk of Failure: An Empirical Investigation, September 2010

3199 Guido Heineck and Bernd Süssmuth, A Different Look at Lenin's Legacy: Trust, Risk, Fairness and Cooperativeness in the two Germanies, September 2010

3200 Ingvild Almås, Tarjei Havnes and Magne Mogstad, Baby Booming Inequality? Demographic Change and Earnings Inequality in Norway, 1967-2000, October 2010

3201 Thomas Aronsson and Sören Blomquist, The Standard Deviation of Life-Length, Retirement Incentives, and Optimal Pension Design, October 2010

3202 Thorvaldur Gylfason and Eduard Hochreiter, Growing Together: Croatia and Latvia, October 2010

3203 Ken Burdett and Melvyn Coles, Tenure and Experience Effects on Wages: A Theory, October 2010

3204 Wendy Carlin, Good Institutions are not enough: Ongoing Challenges of East German Development, October 2010 